\title{
Evaluation of Sequential Aerated Treatment of Wastewater from Hardboard Mill
}

\author{
S. Videla, C. Isaacs, and M. Cristina Diez* \\ Dpto. de Ingeniería Química, Universidad de La Frontera, P.O. Box 54-D, Temuco-Chile.
}

\begin{abstract}
Wastewater from a hardboard mill characterized by a high organic content (15-30 g/L COD) was studied in a bench scale sequential aerated system in order to define a start up strategy. Inlet COD concentration varied from 0.5 to $25 \mathrm{~g} / \mathrm{L}$ and the hydraulic retention time was maintained at 5 days. The sequential system proposed could reduce BOD, COD, TSS and phenol over $90 \%$ except when the inlet COD concentration was lower than $25 \mathrm{~g} / \mathrm{L}$.
\end{abstract}

Key words: Fiber board wastewater, hardboard, sequential aerobic treatment, start up strategy

\section{INTRODUCTION}

Hardboard manufacturing based on a wetprocess requires large quantities of water; which is estimated to be about 15 or $20 \mathrm{~m}^{3} /$ ton (Bjorklund Jansson \& Back, 1976), most of which would be discharged from the mill carrying a variety of contaminants.

In the last decade, forest industry developed a environmental water strategy based on three main steps: reducing water consumption, recycling, and reusing wastewater (3R strategy). Substantial changes were observed in most of the wastewater of old mills as a consequence of applying this environmental strategy (Virkola \& Honkanen, 1985 ; Heyen, 1995). Main impacts of this strategy are build-up concentration and some physico-chemical modifications, such as variations in solid size distribution and increase in viscosity in wastewater (Virkola \& Honkanen, 1985 ; Janson \& Back, 1975). Most of this wastewater, however, is not well characterized partly due to the variety of internal measures applied according to 3R strategy.

A number of fiber building board mills in U.S. and in Europe have adopted some form of biological treatment for their effluents. Both activated sludge systems and aerated lagoons are in use and 60 to $95 \%$ BOD reductions have been reported (Rennefelt, 1965 ; Dewes \& Meyers, 1966). Intermittent decanted aerated reactors (IDAR) have been used by Li et al. (1994) for biological treatment of eucalyptus wood panel industrial wastewater, obtaining removal of 50$80 \%$ of total COD and $90-96 \%$ of total $\mathrm{BOD}_{5}$. The simplest form of biological treatment is an aerated lagoon, in which the nutrient requirements are lower than in the activated sludge treatment, and nutrients can sometimes be omitted. A normal load for an aerated lagoon is about $20-40 \mathrm{gBOD} / \mathrm{m}^{3} /$ day. However, with a conventional BOD-load and concentrated effluent, which occur in fiber building board mills, the retention time would be longer. When large amounts of wastewater with a high BODconcentration are to be treated, a more intensive biological treatment method must be used. Furthermore, the conventional effluent treatment does not seem to be a suitable system to remove high organic loading generates in effluent from closing mills.

Our main objectives were to study a start up methodology of the sequential aerated system and to obtain fundamental data for design and operation of this process. Start up of aerated lagoon feeding with low organic load is a very sound process used for many years in forest industry, but there is a lack of information about sequential aerated treatment, especially of hardboard effluent.

\footnotetext{
* Author for correspondence
} 


\section{MATERIALS AND METHODS}

Hardboard wastewater: The hardboard mill was located in the VIII Region of Chile, started in 1959, the oldest fiberboard manufacturing plant in Chile with an annual turnover of 60.000 ton, using Pinus radiata as raw material. In 1990, this industry adopted an environmental water strategy based on reduction of water consumption, recycling and reusing wastewater. As a consequence of "closing-strategy" applied to this hardboard mill, a $500 \mathrm{~m}^{3} /$ day effluent was generated, with a high organic content of 15-30 g/L COD (Table 1), nearly five times the original concentration. Two internal processes press section and defibrillation are the main source of this effluent. The samples of the Pinus radiata hardboard effluent were taken from the discharge of the mill and stored at $4{ }^{\circ} \mathrm{C}$ for a maximum period of two weeks prior to their use in the lab scale sequential system.

Effluent treatment: A sequential system of two aerated lagoons was used as a biological treatment of the effluent. A set up of the system is shown in Fig. 1. Each lagoon had an aerated zone and a settling zone. In the aerated zone, a diffuser in the bottom of the lagoon supplied air to the liquid phase by means of a compressor to keep the dissolved oxygen above 1 to $2 \mathrm{mg} / \mathrm{L}$. The aerated zone had an effective volume of 4 liter and the settler volume was nearly 1 liter. Hydraulic retention time were 5 days and 2 days in the aerated zone and the settler, respectively. The first lagoon was fed with the hardboard effluent by means of a peristaltic pump at a rate depending on the lagoon conditions, specified for each case.

Table 1. Characteristics of Hardboard Effluent

\begin{tabular}{l|l|cc}
\hline Parameters & Unit & \multicolumn{2}{c}{ RANGE } \\
\hline $\mathrm{pH}$ & & 3.5 & 3.9 \\
Temperature & ${ }^{\circ} \mathrm{C}$ & 50 & 70 \\
Conductivity & $\mu \mathrm{S} / \mathrm{cm}$ & 580 & 1036 \\
Colour & $\mathrm{UPt} / \mathrm{Co}$ & 17650 & 21325 \\
$\mathrm{BOD}$ & $\mathrm{g} / \mathrm{L}$ & 5.6 & 14.7 \\
$\mathrm{COD}$ & $\mathrm{g} / \mathrm{L}$ & 14.9 & 31.6 \\
$\mathrm{TS}$ & $\mathrm{g} / \mathrm{L}$ & 12.5 & 25.4 \\
$\mathrm{VS}$ & $\mathrm{g} / \mathrm{L}$ & 12.0 & 24.5 \\
$\mathrm{TSS}$ & $\mathrm{g} / \mathrm{L}$ & 1.1 & 3.4 \\
Phenol & $\mathrm{mg} / \mathrm{L}$ & 0.5 & 1.03 \\
Tannin \& Lignin & $\mathrm{mg} / \mathrm{L}$ & 760 & 1880 \\
\hline
\end{tabular}

Start up of aerated lagoon: A progressive strategy was implemented to start up the aerated system. Initial conditions corresponded to highly diluted wastewater. From day 0 to 20 , inlet COD concentration of the first lagoon was $0.5 \mathrm{~g} / \mathrm{L}$, from day 20-50, it was gradually increased up to $4.5 \mathrm{~g} / \mathrm{L}$ COD and maintained in this concentration for ten days. From day 60 to 100, the effluent concentration was gradually increased up to $12.5 \mathrm{~g} / \mathrm{L}$ COD and maintained for twenty days. From day 130 to 150 , inlet COD concentration was increased up to $25 \mathrm{~g} / \mathrm{L}$ and maintained for thirty days. In each step an adequate COD:N:P relationship was maintained.
Operational control: Main parameters, such as dissolved oxygen, $\mathrm{pH}, \mathrm{COD}$, and solids (total and suspended) were determined in the inlet and outlet of each lagoon every two days. Dissolved oxygen inside the reactor and $\mathrm{pH}$ in the feed were adjusted when necessary. Soluble phosphate, nitrogen, phenol, and tannin and lignin concentration were periodically evaluated. A mass balance was made to measure removal efficiencies. All evaluated parameters were determined according to Standard Methods (APHA-AWWA-WPCF, 1985). 


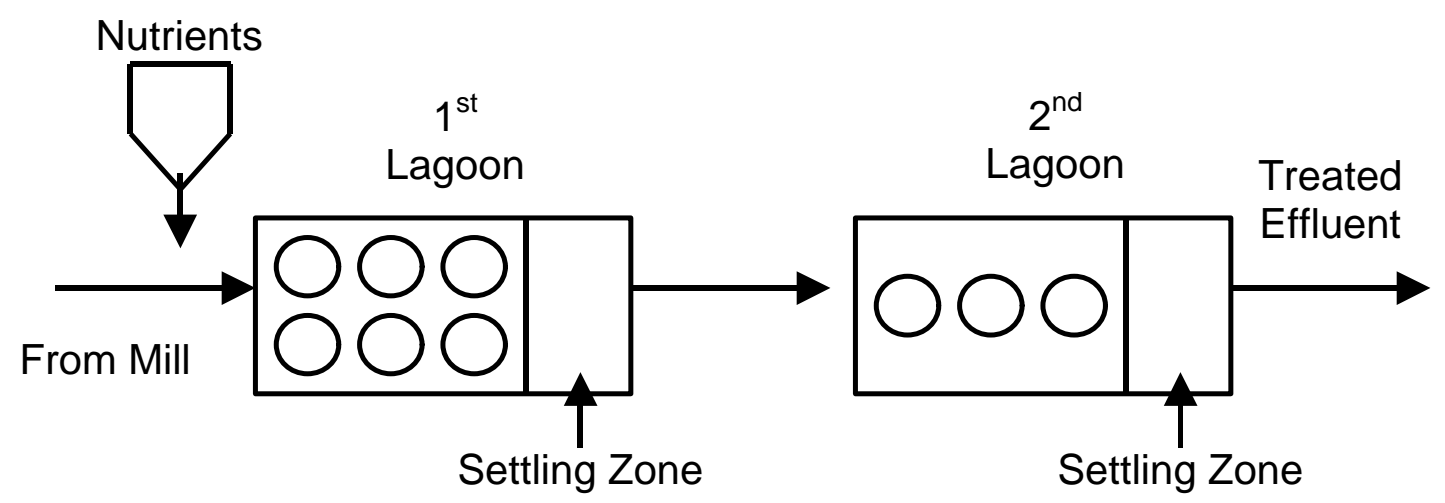

Fig. 1-Schematic diagram of the aerated sequential system

\section{RESULTS AND DISCUSSION}

Figure 2 shows the main daily operational parameters and reactor efficiencies during continuous aerobic treatment of hardboard effluent. The $\mathrm{pH}$ performance during the overall sequential treatment is shown in Fig. 2a. The $\mathrm{pH}$ of the feed was adjusted near 6.0 with $\mathrm{NaOH}$ in the first lagoon. We could see that the $\mathrm{pH}$ in the outlet of the first lagoon was affected by the increase in the COD concentration. Nevertheless, the $\mathrm{pH}$ in the second lagoon was more stable and varied from 6 to 8 until day 140, then the system became unstable and the $\mathrm{pH}$ decreased as a consequence of the highest organic load rate (OLR).

Figure $2 b$ shows results of the dynamics behavior of COD at the inlet and outlet streams of the first lagoon and at the outlet of the second lagoon. Inlet COD varied from $0.5 \mathrm{~g} / \mathrm{L}$ to 25 $\mathrm{g} / \mathrm{L}$. The outlet COD of the first lagoon varied from an initial $0.03 \mathrm{~g} / \mathrm{L}$ COD up to $0.4 \mathrm{~g} / \mathrm{L}$ (day 70 ), then the COD increased slowly up to 3.0 $\mathrm{g} / \mathrm{L}$ on day 120 . From days 130 to 170 , the outlet COD in the first lagoon increased rapidly when the inlet COD increased up to $25 \mathrm{~g} / \mathrm{L}$. The effluent in the second lagoon showed a nearly constant value from day 65 to day $130(0.7 \mathrm{~g} / \mathrm{L}$ COD) and then, the COD increased slowly up to
$6.6 \mathrm{~g} / \mathrm{L}$, as a consequence of the highest COD in the outlet of the first lagoon. It was possible to observe that the COD curves mainly depended on the inlet conditions. Each aerated lagoon corresponded to a continuous stirred bioreactor with a pseudo first order dynamic.

Figure $2 \mathrm{c}$ shows the results in terms of COD removal during the overall sequential aerobic system. We could see that the sequential overall process could reduce COD up to $96 \%$, except when the inlet COD concentration was $25 \mathrm{~g} / \mathrm{L}$. The first lagoon operated as a bio-adsorption unit efficiently reduced COD up to $95 \%$ when the inlet COD concentration was between 0.5 and $6.5 \mathrm{~g} / \mathrm{L}$, then the COD removal decreased slowly down to $81 \%$ when the inlet COD was $12.0 \mathrm{~g} / \mathrm{L}$. The second system showed some initial COD removal variations and increased slowly up to $85 \%$ from days 60 to 130 . From days 130 to day 160, both lagoons presented non-stable, behavior partly due to the increase of inlet COD load.

Table 2 shows the parameters obtained in the sequential aerobic system before increasing the organic load (day 130). We could observe that the system presented high efficiency during the overall period except when the inlet COD concentration was higher than $12 \mathrm{~g} / \mathrm{L}$. 
Table 2. Parameters of sequential treatment system before organic over load (day 130) at the end of the stable period.

\begin{tabular}{l|c|cc|cc|c}
\hline & \multirow{2}{*}{ Influent } & \multicolumn{2}{|c|}{$1^{\text {st }}$ Lagoon } & \multicolumn{2}{c|}{$2^{\text {nd }}$ Lagoon } & Overall \\
& & \multicolumn{2}{|c|}{ Effluent } & \multicolumn{2}{c}{ Effluent } & Removal (\%) \\
\hline BOD $(\mathrm{g} / \mathrm{L})$ & 4.95 & 1.25 & 74.6 & 0.061 & 95.0 & 98.0 \\
COD (g/L) & 12.00 & 3.10 & 74.2 & 0.74 & 76.2 & 93.8 \\
T S (g/L) & 17.6 & 7.41 & 58.0 & 3.66 & 51.0 & 79.0 \\
T S S (g/L) & 3.31 & 0.37 & 88.8 & 0.17 & 54.0 & 94.8 \\
Phenol (mg/L) & 0.99 & 0.389 & 61.0 & 0.029 & 92.5 & 97.0 \\
Tannin \& Lignin (g/L) & 1.12 & 0.38 & 66.0 & 0.20 & 47.0 & 82.0 \\
\hline
\end{tabular}

The removal of BOD, COD, total suspended solids, phenols, and tannin and lignin was very high considering the high organic load present in this type of effluent (Table 2). Similar results were reported by Li et al (7), using intermittent decanted aerated reactors in extended aeration mode, to treat eucalyptus wood panel industrial wastewater. They reported $85-96 \%$ and $50-80 \%$ BOD and COD removal respectively. So, this type of effluent can be treated efficiently using a sequential aerobic system. On the other hand, the high organic concentration of the mill effluent generated a large amount of biological sludge; this was settled in each decanter zone and manually removed each week.

\section{NOMENCLATURE}

$\begin{array}{ll}\text { BOD : } & \text { Biological Oxygen Demand } \\ \text { COD : } & \text { Chemical Oxigen Demand } \\ \text { IDAR: } & \text { Intermittent Decanted Aerated } \\ & \text { Reactors } \\ \text { OLR : } & \text { Organic Load Rate } \\ \text { TS : } & \text { Total Solids } \\ \text { TSS : } & \text { Total Suspended Solids } \\ \text { VS : } & \text { Volatile Solids }\end{array}$

\section{ACKNOWLEDGMENTS}

This research was supported by FONDECYT $\mathrm{N}^{\circ}$ 1950837 and DIDUFRO 9524.

\section{RESUMO}

Água residual proveniente de uma indústria de tabuleiro de fibra dura caracterizada por ter um elevado conteúdo orgânico (15-30 g/L DQO) foi estudada utilizando um sistema arejado seqüêncial de forma a definir uma estratégia de start up. A concentração de DQO na entrada do sistema variou na faixa de $0,5-25 \mathrm{~g} / \mathrm{L}$ e o tempo de residência hidráulico foi mantido em 5 dias. $\mathrm{O}$ sistema seqüêncial proposto reduziu DBO, DQO, SST e fenol sobre $90 \%$ quando a concentração de DQO na entrada foi menor a 25 $\mathrm{g} / \mathrm{L}$.

\section{REFERENCES}

APHA-AWWA-WPCF (1985). Métodos Normalizados para el Análisis de aguas potables y Residuales. $17^{\text {th }}$ Ed., Washington.

Bjorklund Jansson \& Back E.L. (1976). Pollution Abatement in Fiber Building Board Mills. Pure \& Appl Chem., 45: 175180.

Dewes, E., Denne, A., \& Meyers, H. (1966) Wasser Luft Betrieb 10(5), 2.

Heyen, G. (1995). Convirtiendo Fábrica de proceso húmedo a HDF tuve exito total. Wood Technology, July: 4-6.

Janson, M. \& Back, E. (1975). Chemical Characterization of fiber build mill effluent. Wood Science, 8(2):112-121.

Li, X.Z.; Boyden, B.H. \& Sun, D. (1994). Aerobic Treatment of Effluent from Wood Panel industry. IAWQ $17^{\text {th }}$ Biennial International Conference. 24-29 July, Budapest, Hungary.

Rennerfelt, J. (1965). Svensk Papperstid. 68: 53.

Virkola, N.E. \& Honkanen, K. (1985). Wastewater Characteristics. Water Science Technology 17(1):1-28. 